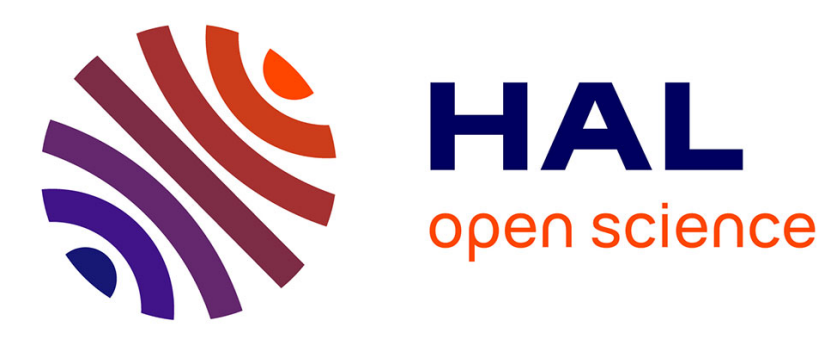

\title{
Which Platonism for Which Modernity? A Note on Shaftesbury's Socratic Sea-Cards
}

\author{
Laurent Jaffro
}

\section{To cite this version:}

Laurent Jaffro. Which Platonism for Which Modernity? A Note on Shaftesbury's Socratic Sea-Cards. Douglas Hedley; Sarah Hutton. Platonism at the Origins of Modernity. Studies on Platonism and Early Modern Philosophy, 196, Springer, pp.255-267, 2008, International Archives of the History Of Ideas, 978-1-4020-6407-4. 10.1007/978-1-4020-6407-4_17. halshs-00264784

\section{HAL Id: halshs-00264784 https://shs.hal.science/halshs-00264784}

Submitted on 6 Jul 2021

HAL is a multi-disciplinary open access archive for the deposit and dissemination of scientific research documents, whether they are published or not. The documents may come from teaching and research institutions in France or abroad, or from public or private research centers.
L'archive ouverte pluridisciplinaire HAL, est destinée au dépôt et à la diffusion de documents scientifiques de niveau recherche, publiés ou non, émanant des établissements d'enseignement et de recherche français ou étrangers, des laboratoires publics ou privés. 
Laurent Jaffro

WHICH PLATONISM FOR WHICH MODERNITY?

A NOTE ON SHAFTESBURY'S SOCRATIC SEA-CARDS

I will not speculate about Shaftesbury's alleged Platonism in his Characteristics of Men, Manners, Opinions, Times (1711). Of course it cannot be denied that the philosophy of the third Earl of Shaftesbury (1671-1713) might sound Platonic, especially when it makes use of such topics as the scale of beauties in The Moralists, a Philosophical Rhapsody. ${ }^{1}$ Besides, it is well known that Shaftesbury's criticism of Hobbes drew heavily on the Cambridge Platonists; his first publication was a preface to Benjamin Whichcote's Select Sermons in 1698, in which he restated the claims of moral realism against the mercenary spirit of Hobbesian ethics. ${ }^{2}$ However the so-called Platonism of Shaftesbury is mainly a reconstruction through which commentators claim to understand Shaftesbury better than he understood himself. For he used to view himself as a disciple of Socrates; in his opinion being a disciple of Socrates meant that he was not a Platonist but a Stoic, insofar as the Stoics drew the ultimate consequences of the Socratic idea of virtue as knowledge.

In this paper, I put aside the controversial question of Shaftesbury's own Platonism and I deal only with Shaftesbury's own conception of Platonism, which is quite different. As for the issue of 'modernity', I will follow the same method. The concept of modernity is as old as modernity itself. The Quarrel between the Ancients and the Moderns used to be one of Shaftesbury's favourite topics of conversation. It would be no exaggeration to say that the subject with which we concern ourselves at present was previously well handled by Shaftesbury himself. He faced our question: does modernity draw on Platonism? As I will suggest, his own answer might be put this way: modernity should, but it cannot.

I focus on a very little known manuscript, the Design of a Socratic History. This 166 page autograph document is kept in the Public Record Office in London and is still unpublished. ${ }^{3}$ I begin with a brief description of the manuscript. After that, I will distinguish several acceptations of 'Platonism' according to Shaftesbury. Then I will 
finish with a glimpse of Shaftesbury's views on Platonic dialogue in his published work, the Characteristics. My main point, contrary to a long prevailing interpretation, is that Shaftesbury was less interested in Plato's doctrine than in his art of writing and poetics of philosophy.

\section{Brief description of the manuscript}

The Design of a Socratic History is the draft of a book on Socrates which Shaftesbury never completed. The third Earl was dithering over several possible titles for his projected book: 'Chartæ Socraticæ' or 'Sermones Socraticæ' or, in English, 'Socratic History' or just 'Socratics'. This refers to Horace's famous phrases in his Art of Poetry — to which I will come back below. We should carefully distinguish between the titles of the projected book, (to put it in English) Socratic Papers or Socratic Discourses, and the title of the project itself which was Design of a Socratic History. This distinction is important since the manuscript contains two very different kinds of materials: first, some materials which pertain directly to the projected book; second, many materials which refer to the writing of the book and consist of instructions, notes, ideas, which are essential to the design of the work, but which the work once completed would have dropped.

In this project on which Shaftesbury had been working from 1703 to 1707, the purpose was to examine the ancient testimonies and especially to compare Plato's Socrates to Xenophon's (long before Johann Jakob Brucker ${ }^{4}$ ) in order to piece together the historical Socrates. The plan for such a task was very simple: a first part (or 'book') would deal with the historical Socrates; a second part would be devoted to the fabulous Socrates. As Shaftesbury puts it in the manuscript:

Idea of this Collection of following Tracts. - The Reason of the Separation of this [second] Book from ye former. that History. this Apocrypha'. \& only Certain Dialogues \& Exercizes of Witt \& learning differently and with more or less Truth from Friends, from Enemyes-Friends Xenophon Plato [...] Enemyes Aristophanes Atheneus Lucian. ${ }^{5}$

The first part was supposed to contain a preface and a Life of Socrates, followed by translations of Xenophon's Memorabilia and Xenophon's Apology, with notes and 
commentaries. The second part was expected to be a series of translations from Xenophon (Economics and Convivium), Aristophanes, Plato's Convivium, Apology, Crito and Phado, with introductions, commentaries and notes. Xenophon was regarded as the true historian of Socrates, while Plato was responsible for the fabrication of a legend ${ }^{6}$. The translations from Plato and Xenophon are not even drafted in the manuscript. They were simply postponed and were never completed. ${ }^{7}$ The substance of the manuscript consists of introductions, discourses and notes, on the one hand, and on the other hand of developments which set out the 'notion' or the 'idea' of the work.

This idea of the work draws on a topic which is a classic of Roman Stoicism: ${ }^{8}$ the name of Socrates will be forgotten and the Socratic light will vanish in a moment. Modernity is on the verge of complete oblivion. As Shaftesbury puts it, only a 'noble genius' could 'lay hold of a small track of light from the Ancients'. 9 According to the third Earl, modern conversation may well hint at Socrates, but only as a legendary figure:

That when I have consider'd I have often thought it a thing very absurd \& unaccountable to hear Antient Names quoted with great Authority when at the same time there was no manner of right understanding or Notion of those talkd of. and whereas a Man would be rediculouse [sic] who should in any grave concern bring instances of Cadmus or Orpheus; yet it is not in itself less absurd when Socrates or any such, being quoted; neither the person that quotes nor any of the standers by $\mathrm{y}^{\mathrm{t}}$ hear, have any Notion who Socrates was $\&$ understand $\&$ conceive his Story as rediculouslly \& fabulously as that of Cadmus or Orpheus. ${ }^{10}$

One might say that this is the same old story of the decay of liberal education. But Shaftesbury was not satisfied with deploring this decay; he tried to remedy the neglect of ancient philosophy in modern conversation. Therefore he decided to put Xenophon and Plato into English and to write some modern Memoirs of Socrates. Several times in the manuscript Shaftesbury mentions another version of the projected book, this one in Latin, which would have been aimed at scholars. ${ }^{11}$ But his priority was obviously to popularize in English the history of Socrates. This was an avant-garde project; for it is 
well known that there is a Platonic and Socratic revival during the eighteenth century, from the thirties onwards, especially in dialogue-writing. Shaftesbury might be regarded as a forerunner of this revival. ${ }^{12}$

It should be noted that Shaftesbury's use of ancient texts is always direct. He quotes occasionally Marsilio Ficino, ${ }^{13}$ Ralph Cudworth, Thomas Stanley and 'Harry Stephens' (Henry Estienne) for their philological skill as commentators, historians or editors, but he regards them more as competitors than as sources.

The stylistic register at which Shaftesbury is aiming in his translations is that of the ease and fluency of fashionable conversation; this is why he thinks that he should prepare himself reading women's writings, especially French. I quote his instructions to himself:

To make a Collection of all sorts of Particles \& elegant conjunctives \& Connective expressions (so necessary to imitate the happy Chain \& continued Tread of the Greek) from $y^{\mathrm{e}}$ polite Women $\&$ also from them all those asseverations in $\mathrm{y}^{\mathrm{e}}$ stead of Oaths, $\tau$ ov $\delta 1 \alpha \& c$. especially remember in $\mathrm{y}^{\mathrm{e}}$ House of Lords. ${ }^{14}$

Not only to read those Luxuriant writers ${ }^{15}$ but even on $y^{\mathrm{e}}$ account of Style some of $\mathrm{y}^{\mathrm{e}}$ politer Novells as Dutchess of Cleves or those best translated or wrote in English. and this cheifly [sic] for the Narration \& way of translating Ces Entretiens (in $\mathrm{y}^{\mathrm{e}}$ Convivium especially) in $\mathrm{y}^{\mathrm{e}}$ Commentaryes; $\mathrm{w}^{\mathrm{ch}}$ have so much of that air \& $\mathrm{y}^{\mathrm{e}}$ more can be given $\mathrm{y}^{\mathrm{e}}$ better. \& for this reason too, to learn the use of sayd he, sayd she, answer'd he, replyed he, $\mathrm{w}^{\mathrm{ch}}$ go so ill in English, \& and are so hard to manage without falling into $\mathrm{y}^{\mathrm{e}}$ contemptible Style: on $\mathrm{w}^{\text {ch }}$ account $\mathrm{y}^{\mathrm{e}}$ Name of $\mathrm{y}^{\mathrm{e}}$ Partyes must (I beleive [sic]) be very often repeated, \& other turns taken. ${ }^{16}$

Shaftesbury wanted to put the Memorabilia of Xenophon into an English version of the language of Madame de Lafayette. 
This brings me to a new question: which style for such a popularization of the history of Socrates? The manner of writing which fits this project is the 'simple style'. I borrow its definition from the Characteristics:

The simple manner, which being the strictest imitation of nature, should of right be the completest in the distribution of its parts, and symmetry of its whole, is yet so far from making any ostentation of method that it conceals the artifice as much as possible, endeavouring only to express the effect of art under the appearance of the greatest ease and negligence. ${ }^{17}$

The simple style in philosophy must be opposed to the sublime and to the methodical style as well. Unlike the sublime, the simple manner sticks to ordinary conversation. Unlike the methodical, it does not make a show of its art and method. Plato is a good example of the sublime; the methodical (or didactical) style prevails in Aristotle; Xenophon is the embodiment of the simple or 'natural' manner of writing.

The point is that this natural style is as artful as the methodical. The simple style looks like a conversation, but it should not be reduced to a conversational style insofar as it conceals its own deeper reasons and significations. It seems to be as superficial as ordinary (that is to say, courtly) conversation, but it is not the same superficiality. With the simple style, the surface opens to a concealed depth.

This is the reason why this manner of writing is the best way to address at the same time two different categories of readers: first, the fashionable society; second, the true philosophers, namely those who know that Christianity is a tale. There are many remarks in the manuscript on Socrates in which it is clear that Shaftesbury was well aware that philosophy must have recourse to some rhetoric. This is obvious in the following passage:

To review the Work \& the translations. particularly so many severall times; in severall Considerations \& under severall Ideas, as first with Respect to the Devout, the Polite the Scoffers \& those $\mathrm{y}^{\mathrm{t}}$ Catch at any Redicule [sic]. The Learn'd (to whome certain necessary Historicall Relations it simply told will seem impertinent) and the Unlearn'd (to whome these are necessary) [...]. 
And in $\mathrm{y}^{\mathrm{e}}$ next place to review in the same manner Plato's translation in $\mathrm{y}^{\mathrm{e}}$ Idea of Plato's Style \& Character viz. Sublime, \& Xenophon's in his viz. Simplicity. remembering this in particular of Xenoph. viz. his facetiousness \& good Humour $\mathrm{w}^{\text {ch }}$ lyes in a manner conceal'd. ${ }^{18}$

Xenophon's omnipresence and his evident primacy over Plato in the Design of a Socratic History should be construed as a supremacy of the simple style. Shaftesbury views Xenophon not only as the best source for writing the history of Socrates, but also as the best model for the very style of this writing. Does it mean that he depreciates Plato? Yes, in a way. But such a statement should be carefully qualified, as I will soon suggest.

The simple style is intended to allow a multilevel (if I may say so) communication. It has the advantage of addressing several levels of reading through a single communication:

Allways to remember the $\mathrm{G}^{\mathrm{t}}$ Mysteryes $\mathrm{w}^{\text {ch }}$ must remain Misteryes [sic] \& think not $\mathrm{y}^{\mathrm{t}}$ wee are writing to Philosophers \& those Philosophers amongst $\mathrm{y}^{\mathrm{e}}$ rest who know Necessity the Nature of Evill — Providence particular \& generall. for to whome must not these things of necessity remain a Mistery? Therefore examine \& judg of every Paragraph with respect to 3 sorts. (1) the Superstitiouse of $\mathrm{y}^{\mathrm{e}}$ finer sort. (2) the morallists of a looser kind \& avers to Platonism \&c. (3) and the Polite people not Schollars or Learnd but Lovers of Notion \& Language. ${ }^{19}$

There are three categories of readers. The priority of Socratics was to address the third one ('polite people, not scholars'). Even if the book would silently address the philosophers (those who know that providence is not a person and that there is no real evil in nature), it is not written for them. At the same time, the book should protect itself against the prejudices or the 'superstitious of the finer sort' who are not the orthodox censors nor Shaftesbury's overt enemies, but his latitudinarian friends who stick to a liberal interpretation of Christianity. 
As for the 'moralists of a looser kind', they are those who were criticised by Christian Platonists. The first of these moralists is Hobbes. Here we have a definition of Platonism. In this general sense, Platonism is realism and especially moral realism which should be opposed both to the divine command theory and to conventionalist accounts or morality. Shaftesbury considers that the Ancients were, as he puts it, 'happily knowing' insofar as they were moral realists. I quote: 'As the Antients excell us in Policy and Government, so in the knowledge of this sort (viz. Morralls [sic]) they were not less happily knowing. ' In the margin of the manuscript, Shaftesbury adds this significant note: 'Take care of the objection, viz. the Morall of the Gospell. '

\section{Three Platonisms}

Now we are able to distinguish three different meanings of 'Platonism'.

1. There is Platonism in the general sense, that is:

— Moral realism and a cognitivist account of morality. In this sense 'Platonism' does not consider morality as subordinate to religion or politics. Morality is primarily a matter of knowledge, not of obedience. Hobbes and Locke are antiPlatonists since they claim that moral properties are relative to conventions, whether human or divine.

- Also, this sense of 'Platonism' may include a diffuse pantheism or at least a naturalism which is common to many schools in ancient philosophy.

Shaftesbury is a Platonist in this general sense. But he is convinced that, because of Hobbist propaganda, modernity is at odds with Platonism in this sense.

2. We have Platonism as Plato's doctrine, to be distinguished from Socrates's views: 'Plato is to be consider'd as writing for Socrates sometimes but often for himself and his own Notions of Education Maxims Philosophy \&c.' Another passage:

Remember to make a kind of Comparison between Plato and Xenoph [sic]. Plato [...] so taken up with Sublime \& Mystical things \& in his Poetick raptures perpetually looses himself as to $\mathrm{w}^{\mathrm{t}}$ regards the Character of Socrates not only 
putting things in his Mouth utterly far from him: but making him sometimes an absolute Sceptick (whence the Claim of Sextus Empericus and $\mathrm{y}^{\mathrm{e}}$ Academicks [...] Sometimes a Sophist \& Caviller. Sometimes a Poet \& Vates in divine fury. doing things wholly out of his Character. ${ }^{20}$

According to Shaftesbury, Plato's doctrine is close to Pythagoras's. In particular, Shaftesbury distinguishes between a Socratic 'practical' core in Plato and what he calls 'higher speculations' or 'metaphysical' or even mystical concerns. ${ }^{21}$ But this mysticism does not obliterate Plato's relevance for the history of ancient philosophy:

That however the Stream be mixt yet there is a pleasure in Drawing from Plato as near the fountain head. so did other great Philosophers (not naming either Epict. Marcus or any of $\mathrm{y}^{\mathrm{e}}$ Stoicks) that were not Platonists \& that perhaps dissented from him in the rest of his Philosophy \& higher Speculations: but that own'd Socrates, \& deriv'd from him as their Cheif. ${ }^{22}$

Concerning this second sense of Platonism, even though Shaftesbury claims that Plato's interpretation of Socrates is distorted by Platonic doctrines, this should be carefully qualified. I will not give a detailed account of Shaftesbury's reading of Plato, but only one particular instance: the interpretation of the Socratic demon. According to the manuscript, Plato gives a character of divinity to Socrates's demon and to Socrates himself:

The aim of Plato to give a Character of Divinity to Socrates. [...]

$\mathrm{y}^{\mathrm{e}} \tau$ o $\delta \alpha \iota \mu$ ovıov, directly $\theta \varepsilon \circ \sigma$, by Plato himself. See Alcibiad. 1 pag. 443. L. 16 [First Alcibiades, 105b, 105e]. ${ }^{23}$

But Plato does not completely yield to a mystical interpretation of the demon. He puts stress on the fact that the demon is a sign and more precisely an inhibiting signal within a political context. About Plato's Apology, Shaftesbury has this shrewd remark: 


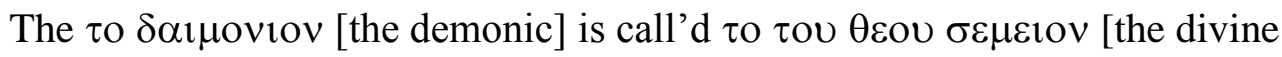

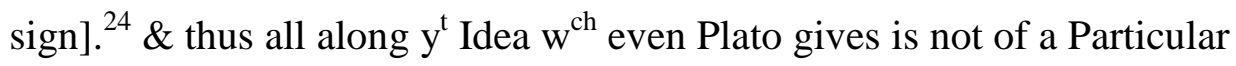
Dæmon or Genius, but a communication from God himself immediatly. \& in the following lines he shews that he had not the Sign (to restrain him from his $\mu \varepsilon \gamma \alpha \lambda \mathrm{o} \gamma \alpha \rho{ }^{2} \alpha$ fine talk] ${ }^{25},[\ldots]$ and he renders a reason why he had not (in $\mathrm{y}^{\mathrm{e}}$ same manner as Xenophon [...]) so $\mathrm{y}^{\mathrm{t}}$ this is rationall \& accountable even here $\mathrm{w}^{\text {th }}$ Plato. $^{26}$

Shaftesbury carefully separates the Platonic and Xenophontic accounts of Socrates's demon from later reconstructions such as those of Plutarch or Apuleus. Plato resists in this particular case his own general inclination to mysticism:

Remember as to $\mathrm{y}^{\mathrm{e}}$ Oracle of Delphos the Commendation of $\mathrm{y}^{\mathrm{e}}$ Oracle \& Priests (upon the Hypothesis of Human Policy \& nothing supernaturall) the assistance given to all the Wise men \& Founders of Republicks [...] Now the oracle pronounc'd in Socrates favour may (upon this Hypothesis) have a double reason. first $y^{t}$ Socrates was really so good and wise $\&$ as such they had correspondance with him as with Lycurgus \&c. \& in $\mathrm{y}^{\mathrm{e}}$ next place that $\mathrm{He}$ being all along carefull to avoid $\mathrm{y}^{\mathrm{e}}$ Character of irreligion so universally at $\mathrm{y}^{\mathrm{t}}$ time imputed to $\mathrm{y}^{\mathrm{e}}$ Philosophers (as particularly Anaxagoras a little before Protagoras at that very time $\&$ in reallity to all $\mathrm{y}^{\mathrm{e}}$ Naturall Philos. \& Sophists) to prevent this he was ever carefull of outward religion $\&$ therefore advic'd consulting of the Oracle Sacrafize $\& c$. (on $w^{\text {ch }}$ account he might have favour) $\&$ constantly taught this to his Disciples whence that constant Character of Piety $y^{t}$ runs through the Life \& writings of Xenoph. that of Plato's going farther by what he drew from Chaldea Egypt Pythagoras \&c. ${ }^{27}$

Xenophon's opinion therefore plain to be gather'd by the diligent Enquirer. Plato's different. But both Xenophon \& even Plato himself utterly contrary to a particular Dæmon distinct from the Great God of $y^{\mathrm{e}}$ World. Now on this ground, one may introduce this discours with Xenophon's opinion, \& say all $\mathrm{y}^{\mathrm{t}}$ is necessary ( $\&$ enough for $\mathrm{y}^{\mathrm{e}}$ Wise) under this shelter of Xenophon's our cheif 
Author's Opinion. afterwards wee may speak of Plato's Opinion; \& afterwards of the succeeding Platonists (who gave so exceedingly into those Notions) \& then Apuleus (the Magician) Plutarch y ${ }^{\mathrm{e}}$ Dæmonist \&c. ${ }^{28}$

3. The last sense of 'Platonism' is Plato's achievement as a poet. Stylistic concerns and the art of writing are very important in Plato. Shaftesbury is obviously a disciple of Plato in this special sense, to which I will get back at the end of this paper.

\section{A Melancholy Conception of Modernity}

Shaftesbury gave up his Socratic project in 1707. At that time he was preparing the publication of A Letter Concerning Enthusiasm, which, in 1711, would be the opening essay of the Characteristics. He was then committed to political and religious controversies and less interested in philology. But we can find an echo of the Design of a Socratic History in the third essay of the Characteristics, Soliloquy or Advice to an Author, which was first published separately in 1710.

In this essay, Shaftesbury considers reason as an inward discourse and applies this Stoic conception of reason to the formation of writers. He recommends modern writers to practice a preparatory discipline of the self, which consists of a secret dialogue with oneself. Since 'our thoughts have generally such an obscure implicit language that it is the hardest thing in the world to make them speak out distinctly', the apprentice writer ought to use a 'vocal looking-glass' in order to make explicit the evaluations that are silently embedded in 'fancies' or 'imaginations' and in the spontaneous use of language. The main aim of that 'self-discoursing practice' is to reduce our mental representations to what they actually consist of, or, to put it in Stoic terms, to transform our mental representations into cognitive or adequate representations. A representation is cognitive or adequate when, pured of any parasitic evaluation, it does not exceed that which it represents and makes us know the object and only the object. For instance, a cognitive representation of the death of a friend should not include the claim that death is an evil. Shaftesbury draws on that somewhat exotic view in order to suggest a new scheme for the education of writers.

In Soliloquy or Advice to an Author, the communication of ideas and the writing of books are viewed as a particular case of what the Roman Stoics used to call duties or offices. According to the Stoics, all social duties and relations are to be prepared by a 
correct application of our judgment, a right appraisal of representations. This is why Shaftesbury advocates the practice of what he calls 'home regimen' or 'self-discourse' as the exact opposite of the modern art of essay-writing or autobiography which was embodied by Montaigne's Essays. Modern writers publish their own readings and more generally their ethical training and the fashioning of their selves; they show to the public what they should keep for themselves. To put it briefly, in Soliloquy Shaftesbury sets out the method and theory of what he has practised in his marvellous private notebooks, the $\alpha \sigma \kappa \varepsilon \mu \alpha \tau \alpha$ (Exercises), ${ }^{29}$ which follow the example of Marcus Aurelius's Meditations.

I deal now with that passage in Soliloquy in which Shaftesbury reuses some materials from the manuscript of the Design of a Socratic History. The passage begins with an interpretation of Horace's famous declaration in his De Arte Poetica:

\section{Scribendi recte, sapere est et principium et fons \\ Rem tibi Socratica poterunt ostendere Charta. \\ [Wisdom is the origin and source of good writing \\ This matter the Socratic pages can teach you.]}

Which Shaftesbury paraphrases by saying:

The skill and grace of writing is founded, as our wise poet tells us, in knowledge and good sense, and not barely in that knowledge which is to be learnt from common authors or the general conversation of the world, but from those particular rules of art, which philosophy alone exhibits. ${ }^{30}$

I insist on this point: the expression 'Chartæ Socraticæ', the 'Socratic pages' to which Shafesbury refers quoting Horace, was first intended to be not only the motto but the title of his projected book on Socrates. Here in his Soliloquy he gives one instance of those Charta Socratica: Plato's dialogues, as if they were not any more suspected of being less faithful and reliable that Xenophon's writings. Plato's dialogues are the 'mimes' or, as Shaftesbury puts it, the 'characterised discourses', which writers should use as 'mirrors' or 'exemplars'. They are the best model for a philosophical education, 
the ideal 'sea-cards' (here Shaftesbury is playing upon the word chartce), that is to say the philosophical maps by which Horace was guided on the ocean of poetry:

Thus much for antiquity and those rules of art, those philosophical sea-cards by which the adventurous geniuses of the times were wont to steer their course and govern their impetuous muse. These were the charta of our Roman master poet, and these the pieces of art, the mirrors, the exemplars he bids us place before our eyes. - Vos exemplaria Graca / Nocturna versate manu, versate diurna ['You should handle Greek examples by night, you should handle them by day']. ${ }^{31}$

But this model is obsolete. Why? It is obsolete because a Platonic dialogue is a mime, which draws on the existing social forms and in particular on conversation. As such, a Platonic dialogue today would be a representation of modern manners, that is to say, of Christian ceremonies.

This is a plain dilemma against that ancient manner of writing which we can neither well imitate nor translate, whatever pleasure or profit we may find in reading those originals. For what shall we do in such a circumstance? What if the fancy takes us and we resolve to try the experiment in modern subjects? See the consequence! - If we avoid ceremony, we are unnatural; if we use it, and appear as we naturally are, as we salute and meet and treat one another, we hate the sight. - What is this but 'hating our own faces'?'

In short, the Platonic dialogues were a picture of simplicity. They were connected to a form of conversation and manners which modernity has lost and which English Whigs admire but fail to restore. The prevailing model in Europe is not the Greek republic, but the Christian monarchy with its formalities. ${ }^{33}$

In the Quarrel between the Ancients and the Moderns, Shaftesbury stands as a defender of the Ancients, but a melancholy one, whose motto is: the golden age is over. If the Moderns were capable of imitating the Ancients, they should do so because the 
Ancients provide the best models; but the Moderns are not even capable of such an imitation.

This melancholy conception of modernity which is set out in Soliloquy should be viewed as a serious rectification of the initial Socratic project. If we pay attention to Shaftesbury's teaching in Soliloquy, we should interpret the Chartee Socratica as a model for a philosophical education. At the time of the writing of his Design of a Socratic History, Shaftesbury was considering that it was possible to frame such a model for the English cultivated readers and even for ladies. He was still convinced that he could adapt the ancient 'Socratic pages' to fit the needs of modern readers. He was determined to provide modernity with new English Charta Socratica. But he did not complete the project; and then in place of it he put the ancient model as worthy of being imitated and at the same time as de facto inimitable, as he makes it clear in his Soliloquy.

This is why in Soliloquy Shaftesbury puts aside the question of the true history of Socrates and of the best sources for writing this history. He focuses on the poetics of the dialogue as a genre and he presents Plato as a poet ${ }^{34}$. Now Platonic 'fables' are not considered any more as being apocryphal stories concerning Socrates, but are valued as artful representations of the 'philosophical hero'.

There was one passage in the manuscript of Socratics which pointed towards this new direction:

What Idea to have of Plato, with what preparation come to read him.

Dramatick Peices [sic] a Tragedy in the lofty Poetick Style \& Fiction. How far regard to Truth in a Tragedy? the same in Plato, main Circumstances preserv'd in these pieces - in others that were no way historicall but meerly metaphisicall [sic] philosophicall Faults of Chronology.

Plato $\mathrm{y}^{\mathrm{e}}$ Poet of Philosophers as Homer $\mathrm{y}^{\mathrm{e}}$ Philosopher of Poets. Panætius see Stanly. ${ }^{35}$ (Observe the Preface of Ficinus, to translate apart. Miscet frequenter gravissimo quodam Consilio utilia dulcibus... Furit enim interdum atque vagatur ut Vates etc.) 
Favourable signification of $\mathrm{y}^{\mathrm{e}}$ word Enthousiasme as to Diety. \& in this Sense Plato a Noble Enthousiast. ${ }^{36}$

This last remark on the positive meaning of the word 'enthusiasm' (which at that time usually signifies 'fanaticism') is very important because it foreruns Shaftesbury's Letter Concerning Enthusiasm which was to appear in 1708.

Soliloquy sets out the idea of the inability of modernity to follow the ancient examples. This pessimistic conception leads Shaftesbury to develop a shrewd analysis of the structure of a Platonic dialogue:

For here the author is annihilated, and the reader, being no way applied to, stands for nobody. The self-interesting parties both vanish at once. The scene presents itself as by chance and undesigned. You are not only left to judge coolly and with indifference of the sense delivered, but of the character, genius, elocution and manner of the persons who deliver it. These two are mere strangers, in whose favour you are no way engaged. ${ }^{37}$

In a letter, a treatise or an essay, there is a communication from the author to the reader. In the case of a dialogue, the communication from the author to the reader is suspended by the intervention of the conversation of literary characters. It is primarily a communication from one character to another. In this sense, the author remains behind the dialogue and is not represented by a particular character. This is the reason why Socrates cannot be Plato's spokesman in the dialogues. Thus Shaftesbury's interpretation of dialogue form as a means of concealment for the author rectifies his former reading of Plato on Socrates. Indeed Plato's Socrates is not the historical Socrates, nor can he be reduced to Plato's double: he is a fictional character.

To summarize my argument, the reappraisal of Plato as a poet is a consequence of the depreciation of Plato as a philosopher. This is very clear in the manuscript when Shaftesbury sketches what could be his best defence of Plato:

Those that would decry Plato, will object that he is ... ... [sic] \& Enthousiastick. Fabulouse ... ... \& full, of Prodigys, of ... ... treating things allegorically in 
Moralls that $\mathrm{He}$ is unsteady changeable tossing to \& fro, transporting from one place into another \& as it were into different regions \& giving no time to rest or examine but filling the Mind with Visions Snatching it from one thing \& hurrying it to another without any naturall transition. abrupt dissapointing. leaving off where there seems most need to pursue \& falling into long (tho' perhaps beautifull) Digressions without measure without bound in fury \& in Transport - All this in some degree true. But then on the other side, $\mathrm{w}^{\mathrm{t}}$ Majesty! what Decorum! what Graces! ${ }^{t}$...... [...] Homericall all this, truly poeticall \& Pindarick [...] Thus also $\mathrm{y}^{\mathrm{e}}$ Objecters may say that He is puerile trifling, full of Sophistry, of Circumlocution, not concise in his Dialect \& use of Logick ... ... But then on $\mathrm{y}^{\mathrm{e}}$ other side, what Politeness what demonstration of Humanity in Conversation, what Antidote to heat \& Animosity $w^{t}$ Good Humour \& Decent Mirth \& Pleasantry throughout (opposite to Moroseness) what Pattern of Conversation? (as it were a Charm to soften rough Dispositions). ${ }^{38}$

To put it briefly, Plato's testimony aboutSocrates is not faithful, but it is at least artful. To rehabilitate Plato, Shaftesbury puts the focus on what I have called the third sense of Platonism - the poetic writing of the dialogue — rather than on Platonic doctrines. Here that which might sound like a postmodernist attention avant la lettre to philosophical writing is actually the most classical awareness:

That as Lucian said he us'd the Philosophicall Weapon Dialogue ag ${ }^{t}$ itself so Plato as to Poetry when in his Repub. he decryes it. ${ }^{39}$

1 Shaftesbury, Characteristics, ed. L. E. Klein (Cambridge: Cambridge University Press, 1999), p. $243 f$.

2 Shaftesbury's edition of Select Sermons is based on a transcript by the Unitarian Thomas Firmin. This material is kept in the Shaftesbury Papers, London, Public Record Office (hereafter PRO), 30/24/24/16-17.

3 The manuscript (PRO, 30/24/27/14) has not received the attention that it deserves. Lawrence E. Klein devotes a few pages to discussing the Design of a Socratic History 
in his Shaftesbury and the Culture of Politeness: Moral Discourse and Cultural Politics in Early 18 $8^{\text {th }}$ Century England (Cambridge: Cambridge University Press, 1994), pp. 107-111. Robert Voitle does not mention it in his biography, The Third Earl of Shaftesbury, 1671-1713 (Baton Rouge and London: Louisiana State University, 1984). I have dealt with the Shaftesburian portrait of Socrates in my essay, 'Le Socrate de Shaftesbury. Comment raconter l'histoire de Socrate aux Modernes', in Ettore Lojacono (ed.) La fortuna di Socrate in occidente, (Florence: Le Monnier Università, 2004), pp. 66-90. The edition of the English text is scheduled in the standard edition of Shaftesbury's writings, which is still in progress: Complete Works, Selected Letters and Posthumous Writings, in English with German Translation, ed. W. Benda, G. Hemmerich, W. Lottes, et al. (Stuttgart: Frommann-Holzboog, 1981- ).

4 According to Louis-André Dorion, Brucker, in his Historia Critica Philosophiae (1742-1744), was the first to proceed to a systematic comparison of Plato's et Xenophon's testimonies on Socrates. See L.-A. Dorion, 'Introduction' to his edition of Xenophon, Mémorables (Paris: Les Belles Lettres, CUF, 2000), pp. viii-ix.

5 PRO, 30/24/27/14, p. 16 (Shaftesbury's original pagination). My transcriptions are literal; misspellings and odd punctuation are kept. Further references to this manuscript (hereafter referred to as Socratics) are given after quotations in the text.

${ }^{6}$ See Socratics, pp. 34-35: 'Plato, for Fact, no farther to be relyed on than either prov'd in other Authors (therefore all those references necessary from the Apology \& other Pieces to the Pieces of Xenoph [sic]) or otherwise when nothing either of ornamt. to his Dialogue Style, Philosophy or the Character of Socrates as a Hero and Divinely inspired comes on his way so that the thing is indifferent.'

${ }^{7}$ It is to be noted that the torch was in a way taken up by Shaftesbury's younger brother, Maurice Ashley, who was to publish a translation from Xenophon: Cyropadia: or, The Institution of Cyrus (London, 1728).

${ }^{8}$ See Marcus Aurelius, Meditations to Himself, VII, 19.

${ }^{9}$ Socratics, p. 82.

10 ibid., p. 2.

${ }^{11}$ See for instance this passage (Socratics, p. 74, crossed out): 'To remember at the End of $\mathrm{y}^{\mathrm{e}}$ Book (after Finis) an Advertisment (of $\mathrm{y}^{\mathrm{e}}$ Printer to $\mathrm{y}^{\mathrm{e}}$ Reader) that $\mathrm{y}^{\mathrm{e}}$ Translator's design being only publick good of Learning if any Lover of this kind will transmitt any 
remark so as to give light to any passage it will be gratefull $\&$ in a Latin Edition design' $d y^{\mathrm{e}}$ person's name be with acknowledgm ${ }^{\mathrm{t}}$ mention'd'.

12 See Michael Prince, Philosophical Dialogue in the British Enlightenment. Theology, Asthetics, and the Novel (Cambridge: Cambridge University Press, 1996), pp. 163189. See also Kevin J. H Berland, 'Didactic, Catechetical, or Obstetricious: Socrates and 18th-Century Dialogue', in K. L. Cope (ed.) Compendious Conversations: Essays on Eighteenth-Century Dialogue (Frankfurt: Peter Lang, 1992), pp. 93-104.

${ }^{13}$ Ficino's preface to his Plato is quoted in Socratics, p. 34; I quote this passage below, p. 8 .

${ }^{14}$ Socratics, p. 52.

15 Here Shaftesbury has Dryden's prefaces in mind.

${ }^{16}$ Socratics, p. 108.

17 Characteristics, ed. L. E. Klein, pp. 115-16.

${ }^{18}$ Socratics, p. 76

${ }^{19}$ ibid., p. 53

20 ibid., p. 35.

21 Shaftesbury distinguishes 'teaching Moralls' from 'philosophizing \& reasoning' (Socratics, p. 111).

22 ibid., p. 78

23 ibid., p. 66.

${ }^{24}$ Shaftesbury is referring to Apology, 40b.

${ }^{25}$ To understand what Shaftesbury has in mind here, we must refer to his comments on the title of Xenophon's Apology: 'The Title apt to cause mistake: $\pi \rho \circ \sigma \tau \mathrm{ov \sigma} \delta \mathrm{i} \alpha \sigma \tau \alpha \sigma$ not Xenophon's appeal or apology to them; but Socrates 's $\mathrm{w}^{\text {ch }}$ is contain'd in it, \& where his Speech to ye Judges is inserted: from $w^{\text {ch }}$ part it has the Name of Apology. tho really it be also an Apology from Xenophon himself who rectifyes other Apologyes \& owning (as may be perceiv'd) the truth of Plato's Apology as to the Main he writes this to prevent the Objection of Magnificent speaking the $\mu \varepsilon \gamma \alpha \lambda \mathrm{o} \gamma \alpha \rho 1 \alpha$ of Socrates so set out by Plato \& others' (Socratics, p. 8).

\footnotetext{
${ }^{26}$ Socratics, p. 62.

${ }^{27}$ ibid., pp. 66-67.

${ }^{28}$ ibid., p. 67.
} 
${ }^{29}$ This two volume manuscript is also kept in the Public Record Office, 30/24/27/10; imperfect and partial edition by Benjamin Rand in The Life, Unpublished Letters, and Philosophical Regimen of Anthony, Earl of Shaftesbury (London: Swan Sonnenschein, 1900). See my French annotated translation, Exercices (Paris: Aubier, 1993).

${ }^{30}$ Characteristics, ed. L. E. Klein, p. 87.

31 Ibid., p. 92.

32 Ibid., pp. 91-92.

${ }^{33}$ It is to be noted that Shaftesbury has recourse to dialogue-writing in The Moralists. A Philosophical Rhapsody (1709), but this dialogue between Philocles and Theocles is related by Philocles within a letter to Palemon, which creates a sort of alienation effect. Shaftesbury often insists on letter-writing as the modern genre par excellence. See Lawrence E. Klein, 'The Theory and Practice of Letter-Writing in the Third Earl of Shaftesbury', in Il gentleman filosofo. Nuovi saggi su Shaftesbury, ed. Giancarlo Carabelli and Paola Zanardi (Padua: Il Poligrafo, 2003), pp. 127-141.

${ }^{34}$ In Socratics (p. 50), commenting on Horace's phrase, stipare Platona Menandro ('packing Plato with Menander', Satires, II, 3, 11), Shaftesbury writes: 'Therefore again he shews $\mathrm{y}^{\mathrm{t}}$ nothing was more divine than Plato, or more usefull even to a Poet: $\mathrm{w}^{\text {ch }}$ place also may shew that Plato was reckon'd amongst the Poets.'

35 Here Shaftesbury is referring to Thomas Stanley's History of Philosophy.

${ }^{36}$ Socratics, p. 34.

37 Characteristics, ed. L. E. Klein, p. 90.

${ }^{38}$ Socratics, pp. $72-73$.

${ }^{39}$ ibid., p. 78. I thank David Leech for his help on an earlier draft of this paper. 